\title{
Witamina C - budowa, właściwości, funkcje i występowanie
} Vitamin C - structure, properties, occurrence and functions

\author{
Katarzyna Janda1, Magdalena Kasprzak², Jolanta Wolska1 \\ ${ }^{1}$ Zakład Biochemii i Żywienia Człowieka Pomorskiego Uniwersytetu Medycznego w Szczecinie \\ ul. Broniewskiego 24,71-460 Szczecin \\ Kierownik: prof. dr hab. n. med. Ewa Stachowska \\ ${ }^{2}$ Absolwentka Wydziału Nauk o Zdrowiu Pomorskiego Uniwersytetu Medycznego w Szczecinie \\ ul. Żołnierska 48, 71-210 Szczecin \\ Dziekan: prof. dr hab. n. zdr. Beata Karakiewicz
}

\section{SUMMARY}

In this paper the structure of vitamin $\mathrm{C}$, its physical and chemical characteristics, and occurrence are presented. The biological role of ascorbic acid, the human body's demand for this vitamin, and its deficiency symptoms are specified. Key words: ascorbic acid, sources, functions, demand.

\section{STRESZCZENIE}

W pracy przedstawiono budowę witaminy C, jej właściwości fizyczne i chemiczne oraz występowanie. Wskazano na rolę biologiczną kwasu askorbinowego, zapotrzebowanie organizmu człowieka na tę witaminę i objawy jej niedoboru.
Słowa kluczowe: kwas askorbinowy, źródła, funkcje, zapotrzebowanie.

\section{WSTĘP}

Historia odkrycia witaminy C wiąże się więc ściśle ze szkorbutem (gnilcem), poszukiwaniem przyczyn tej choroby, sposobu jej leczenia i zapobiegania. Pierwsze objawy szkorbutu zostały opisane w egipskich papirusach z 1550 r. p.n.e. [1]. Już w średniowieczu łączono wpływ sposobu odżywiania na pojawianie się oznak szkorbutu. Najostrzejszy przebieg choroba ta miała na terenach Europy Północnej, gdzie przez większość roku był znikomy dostęp do świeżych warzyw i owoców [2]. Szkorbut dotykał również marynarzy i innych członków załóg odbywających dalekomorskie podróże, którzy pozbawieni byli przez dłuższy czas dostępu do świeżych produktów roślinnych. Dopiero w XIX w. w marynarce angielskiej wprowadzono nakaz spożywania cytryn [1]. Obecnie przypadki zachorowania na gnilec są rzadkością, natomiast zdarzają się stany częściowej hipowitaminozy [2].

Witamina C jest najbardziej znaną i popularną witaminą o wielokierunkowym działaniu na organizm człowieka [3, 4]. Została wyodrębniona po raz pierwszy z papryki przez węgierskiego biochemika Alberta Szent-Görgyiego w 1928 r., za co został on uhonorowany nagrodą Nobla $[2,4]$. Po ustaleniu struktury kwasu askorbinowego w 1933 r. opracowano jego syntezę, przy współudziale szwajcarskiego uczonego polskiego pochodzenia, Tadeusza Reichsteina [2]. Witaminę C nazwano kwasem askorbinowym, ponieważ jej niedobór wywoływał szkorbut (scorbutus) [5].

\section{BIOGENEZA I BUDOWA WITAMINY C}

Większość gatunków zwierząt dzięki posiadaniu w wątrobie enzymu oksydazy L-gulono- $\gamma$-laktonowej jest zdolna do syntezowania w organizmie kwasu L-askorbinowego $[1,2,6,7]$. Wyjątek stanowią małpy, świnki morskie, nietoperze owocożerne, pstrągi, łososie, niektóre ptaki oraz niektóre rasy psów (np. dalmatyńczyk) [1]. Rośliny mają również zdolność do biosyntezy tego związku, najprawdopodobniej dzięki występowaniu enzymu katalizującego - dehydrogenazy galaktono-laktonowej [2]. Człowiek nie posiada szlaków metabolicznych prowadzących do syntezy tej witaminy, w związku z czym musi być ona dostarczana na bieżąco z pożywieniem. Schemat porównujący biosyntezę witaminy C przez rośliny i zwierzęta przedstawiono na rycinie 1.

Kwas askorbinowy jest pochodną sacharydów [9]. W organizmach zwierząt tworzy się z D-glukozy. W roślinach witamina C może powstać z D-glukozy lub z D-galaktozy. Wskazuje to na występowanie dwóch głównych szlaków biosyntezy tej witaminy u roślin [2]. Kwas L-askorbinowy o wzorze sumarycznym $\mathrm{C}_{5} \mathrm{H}_{8} \mathrm{O}_{6}$ jest $\gamma$-laktonem kwasu 2,3-dehydro-L-gulonowego [2]. W 1933 r. ustalono jego wzór strukturalny, który przedstawiono na rycinie 2 . W centrum cząsteczki znajduje się pięcioczłonowy pierścień $\gamma$-laktonowy, który stabilizuje strukturę. Jego rozerwanie prowadzi do oksydatywnego rozpadu kwasu L-askorbinowego na dwa związki - kwas szczawiowy (dwuwęglowy) i kwas L-treonowy (czterowęglowy) [2]. 


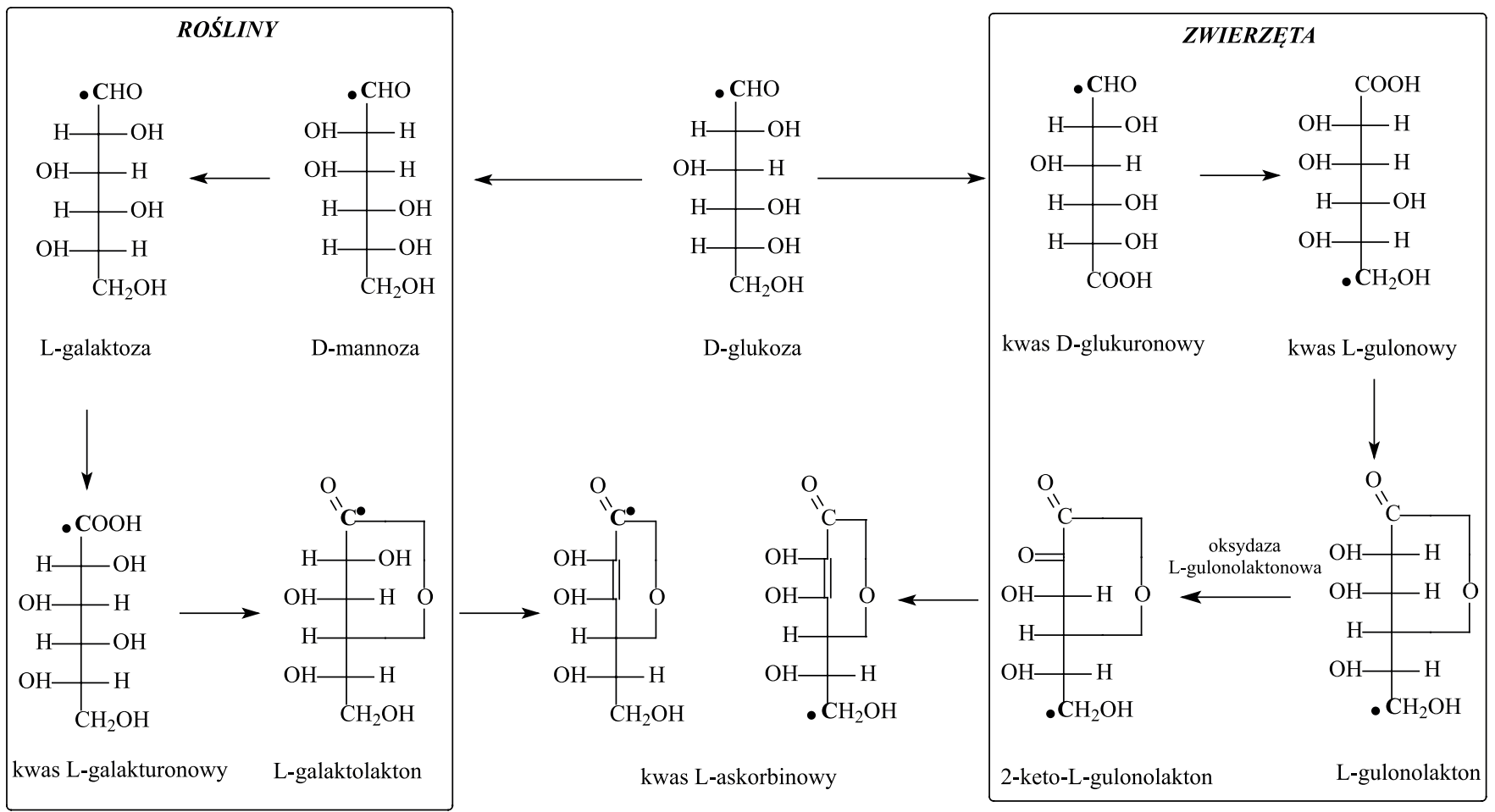

RYCINA 1. Biosynteza witaminy C przez rośliny i zwierzęta [8]<smiles>O=C1OC(C(O)CO)C(O)=C1O</smiles>

RYCINA 2. Wzór strukturalny kwasu L-askorbinowego

Kwas askorbinowy posiada silne właściwości redukujące, ponieważ ugrupowanie pomiędzy C-2 i C-3 (tam gdzie są dwie grupy $\mathrm{OH}$ przy wiązaniu podwójnym), zwane endiolowym, łatwo oddaje po dwa protony i elektrony, przechodząc w ugrupowanie diketonowe kwasu dehydroaskorbinowego. Obecność tego ugrupowania warunkuje silne właściwości redukcyjne i kwasowy charakter kwasu L-askorbinowego [2]. Kwas L-askorbinowy dzięki swoim właściwościom redukującym może w organizmie przekształcać się w kwas L-dehydroaskorbinowy. Jest to utleniona forma kwasu askorbinowego. Obie formy - zredukowana i utleniona - to cząsteczki biologicznie czynne, posiadające taką samą aktywność witaminową [9].

\section{WŁAŚCIWOŚCI FIZYCZNE I CHEMICZNE WITAMINY C}

Najważniejsze właściwości fizyczne kwasu L-askorbinowego przedstawiono w tabeli 1 . Wyizolowana lub syntezowana chemicznie witamina $\mathrm{C}$ to bezwonny biały proszek o delikatnie kwaśnym smaku. Należy do witamin rozpuszczalnych w wodzie (hydrofilowa cząsteczka), a także w rozcieńczonych alkoholach.
TABELA 1. Najważniejsze właściwości fizyczne kwasu L-askorbinowego [2]

\begin{tabular}{|c|c|}
\hline Właściwość & Szczegółowe określenie lub wartość liczbowa \\
\hline Wzór sumaryczny & $\mathrm{C}_{5} \mathrm{H}_{8} \mathrm{O}_{6}$ \\
\hline $\begin{array}{l}\text { Masa } \\
\text { cząsteczkowa }\end{array}$ & $176,13 \mathrm{~g} / \mathrm{mol}$ \\
\hline Postać & $\begin{array}{l}\text { Biała krystaliczna substancja bez zapachu, } \\
\text { o kwaśnym smaku }\end{array}$ \\
\hline $\begin{array}{l}\text { Temperatura } \\
\text { topnienia }\end{array}$ & $190-192^{\circ} \mathrm{C}$ ( z rozkładem $)$ \\
\hline $\begin{array}{l}\text { Rozpuszczalność } \\
(\mathrm{g} / \mathrm{mL})\end{array}$ & $\begin{array}{l}\text { 0,33 w zimnej wodzie i 0,5 w gorącej wodzie; } \\
\text { 0,033 w 95\% i 0,02 w absolutnym etanolu; } \\
\text { 0,01 w glicerolu i 0,05 w glikolu propylenowym; } \\
\text { w eterze etylowym, chloroformie, benzenie } \\
\text { i eterze naftowym nie rozpuszcza się }\end{array}$ \\
\hline Gęstość (g/mL) & 1,65 \\
\hline $\begin{array}{l}\text { Skręcalność } \\
\text { właściwa }\end{array}$ & $\begin{array}{l}{[\alpha]^{25}=+20,5^{\circ} \div+22,5^{\circ}\left(\mathrm{H}_{2} \mathrm{O}\right)} \\
{[\alpha]_{D}^{23}=+48^{\circ} \text { (w metanolu) }}\end{array}$ \\
\hline Potencjat redox & $\mathrm{E}_{0}^{1}=+0,166 \mathrm{~V}($ przy $\mathrm{pH}=4)$ \\
\hline
\end{tabular}

Witamina C posiada charakter kwasowy dzięki zawartości w cząsteczce ugrupowania endiolowego, a w szczególności łatwości dysocjacji protonu grupy hydroksylowej przy C-3. Tworzenie soli, np. askorbinianu wapnia lub żelaza, jest tego potwierdzeniem [2]. Niewątpliwie najważniejszą właściwością kwasu L-askorbinowego jest jego zdolność do tworzenia układu redox - odwracalnego utleniania i redukcji. Utlenianie tego kwasu zachodzi pod wpływem wielu czynników utleniających, jak np. chlorku żelaza(III), nadtlenku wodoru, 2,6-dichlorofenoloindofenolu i innych związków utleniających. Redukcja kwasu L-askorbinowego zachodzi zaś pod wpływem działania np. siarkowodoru czy jodowodoru. Te właściwości redukujące są wykorzystywane do ilościowego oznaczania 
<smiles>C#CCCCCCCO</smiles>

kwas askorbinowy<smiles>O=C1OC(C(O)CO)C(=O)C1=O</smiles>

kwas dehydroaskorbinowy

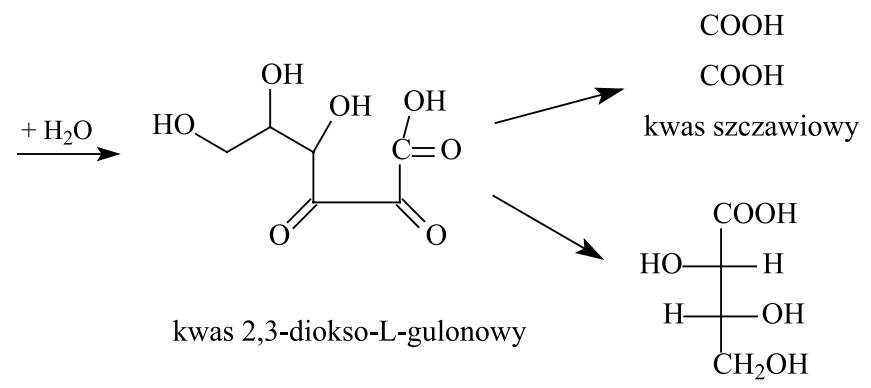

kwas L-treonowy

RYCINA 3. Gtówne etapy przemian kwasu L-askorbinowego

witaminy C w preparatach farmaceutycznych, spożywczych i materiałach biologicznych [2].

Witamina C jest stosunkowo trwała w stanie suchym. W roztworach wodnych ulega rozkładowi pod wpływem wielu różnych czynników: w środowisku alkalicznym lub obojętnym (pH), w wyższej temperaturze, w obecności tlenu, miedzi i żelaza oraz jonów metali [5]. W obecności tlenu stopień rozkładu jest zależny głównie od temperatury i rośnie wraz z jej wzrostem, stąd wysoka termolabilność witaminy C. Roztwory kwasu askorbinowego odznaczają się najwyższą trwałością w zakresie pH 4-6 [2]. Również w warunkach beztlenowych kwas L-askorbinowy jest odporny na działanie wysokiej temperatury. Kwas askorbinowy w tych warunkach jest mniej trwały, co tłumaczy straty witaminy $C$ podczas ogrzewania [9]. Powstający w procesie utleniania kwas dehydroaskorbinowy z czasem ulega nieodwracalnej hydrolizie do kwasu 2,3-diokso-L-gulonowego, który nie posiada już żadnej aktywności witaminowej. Podczas tej hydrolizy następuje rozerwanie pierścienia $\gamma$-laktonowego. Przemiana ta czyni kwas 2,3-diokso-L-gulonowy podatnym na dalsze utlenianie, aż do powstania kwasu szczawiowego i L-treonowego (ryc. 3).

\section{ROLA BIOLOGICZNA ORAZ WCHŁANIANIE WITAMINY C W ORGANIZMIE}

Witamina C jest bardzo aktywna biologicznie. Bierze udział w wielu niezwykle ważnych reakcjach i przemianach, stymulując rożne procesy biochemiczne w organizmie [2]. Dzięki bardzo dobrej rozpuszczalności witaminy C oraz aktywnego transportu jest ona wchłaniana organizmie w ok. 70-80\% (z dawki 180 mg u osób niepalących) [5, 10]. Główne narządy, w których odbywa się proces wchłaniania, to dwunastnica i proksymalny odcinek jelita cienkiego [3, 10]. Sprawność tego procesu w dużej mierze jest zależna od stanu organizmu. Mogą upośledzać go wymioty, brak łaknienia, zaburzenia trawienia oraz wchłaniania, zaburzenia czynności jelit, palenie papierosów i stosowanie niektórych leków (np. aspiryny) [3, 5]. Zapasy witaminy $\mathrm{C}$ w organizmie są niewielkie, przeciętnie wynoszą ok. $20 \mathrm{mg} / \mathrm{kg}$ masy ciała [7]. Największe jej ilości znajdują się w organach odznaczających się wysoką aktywnością metaboliczną: nadnerczach, mózgu, wątrobie, gruczołach śluzowych, trzustce oraz płucach. Glutation oraz pozostałe związki z grupami tiolowymi chronią witaminę C przez utlenieniem. Wysokie ilości tej witaminy pobierają płytki krwi i limfocyty [5].

\section{WITAMINA C JAKO ANTYOKSYDANT I DONOR ELEKTRONÓW}

Unikalna struktura kwasu askorbinowego, który zawiera dwie sąsiadujące grupy, hydroksylową i karbonylową, czyni tę cząsteczkę doskonałym donorem wodoru lub elektronów [11]. Kwas askorbinowy może być dawcą dwóch elektronów, w związku z tym bierze udział jako kofaktor w wielu reakcjach enzymatycznych zachodzących w organizmie [12]. Kwas L-askorbinowy ulega utlenieniu i przekształca się w anion askorbinowy, który oddając jeden elektron, staje się rodnikiem askorbylowym. To cząsteczka, która jest stosunkowo stabilna i trwała w wyniku delokalizacji elektronów. Anion askorbylowy może kontynuować przekazywanie elektronu, prowadząc do przekształcenia się w rodnik askorbylowi, a ten w kwas dehydroaskorbinowy [11,12]. Anion askorbinowy może też zostać z powrotem zredukowany do kwasu askorbinowego poprzez mechanizmy NADPH-zależne i niezależne. Kwas dehydroaskorbinowy może być przekształcony z powrotem do kwasu askorbinowego lub ulec hydrolizie do nieaktywnego kwasu 2,3-dwuketogulonowego, który ulega dalszemu rozkładowi do kwasu szczawiowego [11,12]. Przedstawione na rycinie 4 związki posiadają zdolność do unieszkodliwiania reaktywnych form tlenu [12].

Rodnik kwasu askorbinowego może służyć jako donor elektronów, przyspieszając reakcję redox w obecności metali przejściowych, takich jak żelazo lub miedź [2].

Witamina C jest najbardziej znanym antyoksydantem. Dzięki właściwościom przeciwutleniającym witamina ta pełni ochronną rolę w chorobach serca i naczyń krwionośnych. Zhang i wsp. [13] w badaniach przeprowadzonym na osobach palących papierosy dowiedli, że kwas askorbinowy wraz z innymi przeciwutleniaczami (m.in. witaminą E) hamują podwyższone markery peroksydacji lipidów wywołane paleniem tytoniu u osób palących. Potwierdzono, że antyoksydanty, w tym witamina C, pełnią ochronną rolę w chorobie wieńcowej serca i chorób sercowo-naczyniowych. Dzięki zdolnościom antyoksydacyjnym kwas askorbinowy chroni komórki organizmu przed stresem oksydacyjnym [13]. 
<smiles>O=C1OC(C(O)CO)C(O)=C1O</smiles>

kwas askorbinowy

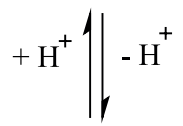<smiles>O=C1OC(C(O)CO)C([O-])=C1O</smiles>

anion askorbinowy<smiles>O=C1OC(C(O)CO)C(=O)C1=O</smiles>

dehydroaskorbinowy

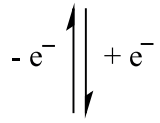<smiles>O=C1OC(C(O)CO)C([O-])=C1[O-]</smiles>

rodnik askorbylowy

RYCINA 4. Przemiany kwasu askorbinowego [12]

\section{PROTEKCYJNE DZIAŁANIE WITAMINY C W ZACHOROWANIU NA NOWOTWORY}

Reaktywne formy tlenu w warunkach homeostazy pełnią bardzo ważną rolę w różnorodnych procesach biologicznych. W momencie nagromadzenia się ich pod wpływem działania czynników, zarówno wewnętrznych (powstające w metabolizmie komórki), jaki zewnętrznych (palenie papierosów, stres), zostaje zaburzona równowaga oksydoredukcyjna. W takim przypadku reaktywne form tlenu wywierają negatywny wpływ na każdą komórkę organizmu, wywołując zmiany m.in. w DNA (błędy podczas replikacji, jak mutacje punktowe i delecje), czy inicjując procesy kancerogenezy [11]. Dzięki silnym zdolnościom antyoksydacyjnym witamina $\mathrm{C}$ „wymiata” wolne rodniki, zmniejszając ilość uszkodzeń na poziomie DNA, ale również uszkodzeń białek i lipidów, obniżając tym samym ryzyko rozwoju nowotworów, zwłaszcza żołądka i przełyku [12]. Kwas askorbinowy podawany doustnie, podobnie jak witaminy A i E oraz selen, wykazuje działanie kardioprotekcyjne wskutek ograniczania peroksydacji lipidów [14]. Chroni także przed tworzeniem się mutagennych N-nitrozozwiązków poprzez blokowanie przemiany azotanów do rakotwórczych nitrozoamin [15]. W żołądku azotany przy udziale bakterii m.in. Helicobacter pylori przekształcają się w azotyny, a te z kolei podczas reakcji nitrozowania w nitrozoaminy. Kwas askorbinowy hamuje działanie zarówno bakterii w żołądku, jak i reakcję nitrozowania. Redukuje groźne azotyny do tlenku azotu [15]. Witamina ta jest również ważna dla prawidłowego funkcjonowania układu odpornościowego, gdyż uczestniczy w procesach immunomodulacyjnych oraz stymuluje syntezę interferonu. Ponadto zwiększa (in vivo) odporność poprzez aktywność komórek NK (natural killer), a także aktywność limfocytów B i T, które oprócz zwalczania patogenów eliminują również komórki nowotworowe [15]. Kwas askorbinowy wpływa także na migrację i aktywność granulocytów, makrofagów i monocytów oraz tworzenie się niektórych klas immunoglobulin [10].

\section{BIOSYNTEZA KOLAGENU}

Biosynteza kolagenu jest jedną z najważniejszych funkcji biologicznych witaminy $\mathrm{C}$ w organizmie. Według rożnych źródeł kolagen stanowi 25-40\% ogólnej ilości białka w organizmie zwierzęcym [2]. Jest to białko występujące w skórze, zębach, kościach, tkance łącznej, chrząstce i rogówce oka. Rola, jaką pełni kwas askorbinowy w biosyntezie kolagenu, polega na jego uczestnictwie w hydroksylacji reszt proliny, a także lizyny do hydroksyproliny oraz hydroksylizyny. Dostarcza elektrony enzymom uczestniczącym w hydroksylacji [10], co skutkuje przekształceniem prokolagenu we właściwy kolagen $[2,16]$.

\section{POZOSTAŁE WAŻNE FUNKCJE BIOLOGICZNE WITAMINY C}

Witamina C jest wysoce aktywną biologicznie cząsteczką i poza wymieniowymi pełni w organizmie wiele dodatkowych funkcji:

- bierze udział w syntezie hormonów i transmiterów [7] jednym z takich hormonów jest noradrenalina, do której syntezy konieczny jej kwas askorbinowy jako dawca elektronów [2],

- współdziała z hydroksylazami uczestniczącymi w przemianach steroidów, tłuszczów (np. cholesterolu do kwasów żółciowych) i niektórych leków (np. leków będących związkami aromatycznymi) [2],

- zwiększa przyswajanie żelaza niehemowego oraz wapnia - kwas askorbinowy redukuje żelazo(III) do żelaza(II) w jednoelektrodowej reakcji, samemu przekształcając się w kwas monodehydroaskorbinowy [2], co z kolei ma istotne 
znaczenie, ponieważ żelazo jest absorbowanie w dwunastnicy w postaci zredukowanej Fe(II) [16],

- jest niezbędna w przebiegu prawidłowej oksydatywnej degradacji tyrozyny [2],

- regeneruje tokoferol z jego postaci wolnorodnikowej [7],

- bierze udział w biosyntezie karnityny (kwasu 4-N-trim etylo-3-hydroksymasłowego) [2],

- bierze udział w odbudowie tkanek podczas gojenia się ran [17],

- reguluje ciśnienie tętnicze [17],

- pomaga w utrzymaniu zdrowych dziąseł [17],

- obniża stężenie glukozy we krwi w stanach hiperglikemii [17] oraz obniża poziomu cukru we krwi na czczo u chorych na cukrzycę [18].

\section{ZAWARTOŚĆ WITAMINY C W NAPARACH}

Kwas askorbinowy jest bardzo dobrze rozpuszczalny w wodzie, dzięki czemu podczas parzenia surowców roślinnych, które są jego źródłem, może przechodzić do naparów. Witamina C jest jednocześnie nietrwała i ulega rozkładowi już podczas zbierania surowca roślinnego. Jest wrażliwa na światło, ciepło i wysoką temperaturę, co sprawia, że podczas parzenia jej część ulega rozkładowi. Badania wykazują, że zawartość witaminy $\mathrm{C}$ w naparach jest uzależniona od różnych czynników, m.in. krotności zaparzania surowca, czasu i temperatury parzenia oraz fazy rozwojowej surowca roślinnego wykorzystanego do przygotowania naparu. Dmowski i wsp. [19] badali wybrane napary Yerba mate (Ilex paraguariensis) pod kątem zawartości witaminy C. Przygotowanie naparów polegało na zalaniu $3 \mathrm{~g}$ surowca wodą o temperaturze $85^{\circ} \mathrm{C}$. Po upływie 3 min napar przesączano, a pozostałą część Yerba mate ponownie zalewano wodą i zaparzano. Proces ten został powtórzony 3-krotnie dla każdej próbki. Wykazano znaczący wpływ krotności parzenia na zawartość witaminy C. Poszczególne napary różniły się znacznie ilością witaminy $\mathrm{C}$, która mieściła się w przedziale 8-19 mg kwasu askorbinowego/100 mL naparu.

Z kolei Yuan i wsp. [20] badali zawartość witaminy C w chińskiej herbacie Hawk (Litsea coreana var. lanuginose). Jest to jedna z najbardziej popularnych herbat ziołowych w południowo-zachodniej części Chin, którą wytwarza się z pąków lub liści Litsea coreana var. lanuginose [20]. Ze względu na różne pory zbiorów herbatę Hawk można podzielić na trzy rodzaje: herbatę z paczków, z młodych liści i herbatę z dojrzałych liści [20]. Udowodniono, że zawartość witaminy C w surowcu, a następnie w przygotowywanych z niego naparach zależy od fazy rozwojowej rośliny. Najwyższą zawartością witaminy C charakteryzowała się herbata z pączków (21,67 mg/100 mL naparu). Herbata z młodych liści zawierała jej nieco mniej (19,87 mg/100 mL naparu), natomiast z liści dojrzałych była ubogim źródłem tej witaminy $(3,15 \mathrm{mg} / 100 \mathrm{~mL}$ naparu) [20]. Z kolei badania prowadzone z wykorzystaniem liści pokrzywy zwyczajnej wykazały, że zawierają one ok. 30-36 mg\% kwasu askorbinowego, podczas gdy do naparu przechodzi on w ilości zaledwie 0,030-0,033 mg\% [21].

\section{KWAS ASKORBINOWY JAKO DODATEK DO ŻYWNOŚCI}

Ze względu na swoje właściwości redukujące i przeciwutleniające kwas askorbinowy jest stosowany powszechnie jako dodatek do żywności. Przeciwutleniacze w żywności są substancjami, które przedłużają trwałość środków spożywczych poprzez hamowanie reakcji utleniania. Zapobiegają niekorzystnym zmianom chemicznym, m.in. w takich grupach żywności jak tłuszcze, owoce i warzywa oraz ich przetwory [7]. Kwas askorbinowy jako dodatek do żywności produkowany jest syntetycznie. Jako antyoksydant posiada silne działanie chroniące produkt spożywczy przed przebarwieniami, zarówno nieenzymatycznymi, jak i wynikającymi z reakcji enzymatycznego brunatnienia. W tym drugim procesie redukuje orto-chinowe produkty [9]. Posiada również działanie zakwaszające lub konserwujące produkty spożywcze [22]. Ponadto hamuje skutecznie tworzenie się trujących nitrozoamin w peklowanych mięsach, jak i stabilizuje kolor mięsa [9]. Kwas askorbinowy jako jeden z dodatków do żywności posiada symbol E 300. Jako przeciwutleniacze stosuje się również jego sole lub estry (tab. 2). Uważa się, że kwas askorbinowy oraz jego sole i estry dodane do żywności są substancjami prozdrowotnymi, ponieważ ich działanie na organizm jest identyczne jak naturalnej witaminy C [22].

TABELA 2. Wykaz dozwolonych przeciwutleniaczy pochodnych witaminy $\mathrm{C}[22]$

\begin{tabular}{ll}
\multicolumn{1}{c}{$\begin{array}{c}\text { Numer wg systemu oznaczeń } \\
\text { Unii Europejskiej }\end{array}$} & \multicolumn{1}{c}{ Nazwa } \\
\hline E 300 & kwas askorbinowy \\
\hline E 301 & askorbinian sodu \\
\hline E 302 & askorbinian wapnia \\
\hline E 304 & estry kwasów tłuszczowych \\
& i kwasu askorbinowego \\
\hline
\end{tabular}

\section{WYSTĘPOWANIE WITAMINY C W ŻYWNOŚCI}

Witamina $\mathrm{C}$ występuje głównie w produktach roślinnych: owocach, warzywach i ziołach. Jej zawartość w naturalnych produktach jest jednak zmienna, zależy od gatunku, odmiany, pory roku, warunków agrometeorologicznych, sposobu przechowywania i przygotowania potraw. Dowiedziono, że zawartość witaminy $\mathrm{C}$ może się różnić w regionalnych odmianach roślin w zależności od kraju pochodzenia. Przykładem mogą być banany, które w Pakistanie są uznawane za bogate w kwas askorbinowy, zaś w Stanach Zjednoczonych uchodzą za ubogie źródło tej witaminy [23]. W związku z tym tabelaryczne zestawienia zawartości witaminy $\mathrm{C}$ w surowcach roślinnych według różnych autorów mogą się nawet znacznie różnić. W tabeli 3 przedstawiono przykładowe średnie zawartości witaminy $\mathrm{C}$ w warzywach i owocach.

Wśród innych surowców roślinnych charakteryzujących się dużą zawartością witaminy C na szczególną uwagę zasługują: rokitnik (do $900 \mathrm{mg}$ witaminy C/100 g świeżej masy 
TABELA 3. Zawartość witaminy C warzywach i owocach $[1,7]$

\begin{tabular}{lc}
\multicolumn{1}{c}{ Surowiec } & $\begin{array}{c}\text { Zawartość witaminy C } \\
\text { (mg/100 g świeżej masy produktu) }\end{array}$ \\
\hline Warzywa & \\
papryka & $125-200$ \\
pietruszka - nać & 269 \\
brukselka & $65-145$ \\
kalarepa & $70-100$ \\
brokuty & $65-150$ \\
kapusta & $35-70$ \\
kalafior & $37-70$ \\
szpinak & $40-84$ \\
cykoria & $6-33$ \\
fasolka szparagowa & $25-30$ \\
rzodkiewka & 25 \\
sałata & $12-30$ \\
pomidory & $5-33$ \\
marchew & 2 \\
buraki & 8 \\
ziemniaki wiosenne & $20-33$ \\
ziemniaki zimowe & $7-8$ \\
\hline Owoce & \\
owoce dzikiej róży & $250-800$ \\
czarne porzeczki & $150-300$ \\
truskawki & $46-90$ \\
kiwi & 84 \\
grejpfruty & $30-70$ \\
cytryny & $40-60$ \\
pomarańcze & $30-50$ \\
porzeczki czerwone i białe & $26-63$ \\
agrest & $25-40$ \\
maliny & $19-37$ \\
jabłka & $0,5-20$ \\
gruszki & 4 \\
śliwki & 5 \\
banany & \\
orzechy włoskie & \\
\hline & \\
\hline
\end{tabular}

TABELA 4. Zawartość witaminy C w mięsie, nabiale i innych produktach $[1,2]$

\begin{tabular}{lc}
\multicolumn{1}{c}{ Surowiec } & $\begin{array}{c}\text { Zawartość witaminy C } \\
\text { (mg/100 g produktu) }\end{array}$ \\
\hline Mięso i przetwory mięsne & 2 \\
mięso (wołowe lub & 30 \\
wieprzowe) & 23 \\
nerki, wątroba & 3 \\
wątróbki drobiowe & \\
ryby & $3-6$ \\
\hline Nabiał & $1-2$ \\
mleko kobiece & 1 \\
mleko krowie & \\
kefir, jogurt (2\% tłuszczu) & $150-250$ \\
\hline Inne produkty & 200 \\
igliwie sosny i świerka & $160-180$ \\
lucerna & 100 \\
owoce głogu & 3000 \\
owoce jarzębiny & \\
orzechy włoskie niedojrzałe &
\end{tabular}

produktu), ziele pokrzywy (do $600 \mathrm{mg}$ ), cytryniec chiński (do $580 \mathrm{mg}$ ), liście lebiodki pospolitej (do $565 \mathrm{mg}$ ) oraz szczypiorek (do $524 \mathrm{mg}$ ) [4]. Witaminę C można znaleźć również w organach zwierząt: mózgu, nerkach i wątrobie. W mleku i mięsie znajdują się jej śladowe ilości lub jej brak (tab. 4).

Źródłem kwasu askorbinowego mogą być również miody. Buba i wsp. [24] wykazali, że miody pochodzące z północno-wschodniej Nigerii zawierają od niespełna 19 do ponad 25 mg witaminy C w 100 g miodu. W Polsce do głównych źródeł witaminy C zaliczane są ziemniaki oraz warzywa kapustne, przede wszystkim ze względu na powszechne i wysokie spożycie [7].

Procesy technologiczne z zastosowaniem wysokiej temperatury, np. suszenie konwekcyjne, odgrzewanie potraw, ale także zbyt szybkie rozmrażanie wpływają na przyspieszony rozkład witaminy C. Straty witaminy C podczas obróbki kulinarnej mogą sięgać od 20\% podczas przygotowywania surówek, aż do 50\% w przypadku gotowania warzyw [7]. Z powodu bardzo dobrej rozpuszczalności witaminy $\mathrm{C} w$ wodzie podczas gotowania surowców roślinnych następuje wymywanie i przechodzenie tej witaminy do wywaru. W związku z tym, aby zminimalizować straty witamin rozpuszczalnych w wodzie, m.in. witaminy C, zaleca się gotowanie warzyw na parze. Również długie przechowywanie warzyw i owoców oraz przetworów, zwłaszcza w nieodpowiednich warunkach, prowadzi do szybkiej utraty tej witaminy [25]. Niewłaściwe przechowywanie ziemniaków powoduje, że mogą one tracić do $15 \%$ witaminy C miesięcznie [7]. W celu zachowania jak największej ilości witaminy $\mathrm{C}$ w żywności zalecane jest jej utrwalanie poprzez mrożenie lub kiszenie [2]. Ważną rolę w przyspieszaniu utleniania witaminy C odgrywają również enzymy z grupy oksydaz (oksydaza polifenolowa i askorbinianowa oraz peroksydaza), które występują w niektórych surowcach roślinnych [7]. Wyraźnie uaktywniają się one w uszkodzonych tkankach roślinnych, więc w przetwarzanych surowcach (przeciery, pulpy) straty następują bardzo szybko [2].

\section{ZAPOTRZEBOWANIE ORGANIZMU NA WITAMINĘ C, NIEDOBORY I TOKSYCZNOŚĆ KWASU ASKORBINOWEGO}

Zapotrzebowanie na witaminę C jest zróżnicowane i zależne od wielu czynników, takich jak wiek, płeć i stan fizjologiczny. W tabeli 5 zestawiono zapotrzebowanie na witaminę $\mathrm{C}$ na poziomie średniego zapotrzebowanie dla grupy (estimated average requirement - EAR), zalecanego spożycia (recommended dietary allowances - RDA) i wystarczającego spożycia (adequate intake - AI) dla poszczególnych grup ludności populacji polskiej.

Zwiększone zapotrzebowanie na witaminę $\mathrm{C}$ występuje u osób z nadciśnieniem tętniczym, palących papierosy (o 40 mg większe zapotrzebowanie niż u osób niepalących), alkoholików, diabetyków, kobiet w ciąży i karmiących, a także u ludzi stosujących pewne leki i będących pod wpływem ciągłego stresu [7]. Wzrasta przy ciężkim, długotrwałym wysiłku fizycznym, podczas wymiotów, braku łaknienia oraz zaburzeń czynności jelit [17].

Ważniejsze objawy niedoboru kwasu askorbinowego to gnilec (szkorbut), występujący obecnie bardzo rzadko jako stan głębokiego niedoboru tej witaminy. Hipowitaminoza objawiać się może osłabieniem organizmu, zwiększoną podatnością na infekcje i zmęczenie, zmniejszeniem wydolności fizycznej, 
TABELA 5. Normy zapotrzebowania grup ludności na witaminę C [17]

\begin{tabular}{|c|c|c|c|}
\hline \multirow{2}{*}{$\begin{array}{c}\text { Grupa } \\
\text { płeć, wiek (lata) }\end{array}$} & \multicolumn{3}{|c|}{ mg witaminy C/dobę } \\
\hline & EAR & RDA & Al \\
\hline \multicolumn{4}{|l|}{ Niemowlęta } \\
\hline $0-0,5$ & & & 40 \\
\hline $0,5-1$ & & & 50 \\
\hline \multicolumn{4}{|l|}{ Dzieci } \\
\hline $1-3$ & 30 & 40 & \\
\hline $4-6$ & 40 & 50 & \\
\hline $7-9$ & 40 & 50 & \\
\hline \multicolumn{4}{|l|}{ Chłopcy } \\
\hline $10-12$ & 40 & 50 & \\
\hline $13-15$ & 65 & 75 & \\
\hline $16-18$ & 65 & 75 & \\
\hline \multicolumn{4}{|l|}{ Dziewczęta } \\
\hline $10-12$ & 40 & 50 & \\
\hline $13-15$ & 55 & 65 & \\
\hline $16-18$ & 55 & 65 & \\
\hline \multicolumn{4}{|l|}{ Mężczyźni } \\
\hline$\geq 19$ & 75 & 90 & \\
\hline \multicolumn{4}{|l|}{ Kobiety } \\
\hline$\geq 19$ & 60 & 75 & \\
\hline \multicolumn{4}{|l|}{ Kobiety ciężarne } \\
\hline$<19$ & 65 & 80 & \\
\hline$\geq 19$ & 70 & 85 & \\
\hline \multicolumn{4}{|l|}{ Kobiety karmiące } \\
\hline$<19$ & 95 & 115 & \\
\hline$\geq 19$ & 100 & 120 & \\
\hline \multicolumn{4}{|c|}{$\begin{array}{l}\text { EAR - średnie zapotrzebowanie dla grupy, RDA - zalecane spożycie, } \\
\text { Al - wystarczające spożycie }\end{array}$} \\
\hline
\end{tabular}

pogorszeniem gojenia się ran, krwawieniem dziąseł, zaburzeniami w tworzeniu kolagenu oraz upośledzeniem wszystkich innych procesów, w których witamina C jest niezbędna i bierze udział. Dodatkowo długotrwałe niedobory witaminy C potęgować mogą powstawanie zmian aterogennych, nowotworowych oraz miażdżycowych, a także podwyższać ciśnienie tętnicze krwi [3, 7]. Osoby starsze, w podeszłym wieku, alkoholicy, ludzie palący papierosy oraz zażywający niektóre leki (np. aspirynę, sulfonamidy, barbiturany) należą do grupy narażonej na niedobory witaminy C $[3,7]$.

Toksyczność kwasu askorbinowego nie jest znana [26], jednak bardzo wysokie dawki (powyżej kilku gramów) u osób chorych na anemią sierpowatą mogą wywołać ostry kryzys komórek sierpowatych. Tak wysokie dawki mogą również spowodować biegunkę hiperosmotyczną [21]. Organizm broni się przed zbyt wysokimi dawkami witaminy C poprzez ograniczenie jej wchłaniania i wydalanie nadmiaru z moczem. Jednakże bardzo wysokie dawki powodują zwiększanie wydalania kwasu moczowego i szczawianów, co może doprowadzić do powstawania kamieni nerkowych [22].

Niniejsza praca nie wyczerpuje zagadnień związanych z kwasem askorbinowym, zwłaszcza jego znaczeniem dla zdrowia. Wyniki prac naukowych wskazują, że witamina C odgrywa niezwykle istotną rolę w przeciwdziałaniu oraz leczeniu wielu poważnych chorób, w tym również nowotworowych. Należy o tym pamiętać, uwzględniając bogate, tanie i łatwo dostępne źródła tej witaminy w codziennej diecie.

\section{PIŚMIENNICTWO}

1. Szczypka M., Gajewska J.: ABC witamin i minerałów. Egros, Warszawa 2000, 38-42.

2. Moszczyński P., Pyć R.: Biochemia witamin. Witaminy lipofilne i kwas askorbinowy. Część II. PWN, Warszawa 1999, 112-136.

3. Kleszczewska E.: Biologiczne znaczenie witaminy C ze szczególnym uwzględnieniem jej znaczenia w metabolizmie skóry. Pol Merkuriusz Lek. 2007, 138 (23), 462-465.

4. Nowak R.: Natura - niedoceniane źródło kwasu askorbinowego. Post Fitoter. 2004, 1, 14-18.

5. Maćkowiak K., Torliński L.: Współczesne poglądy na rolę witaminy C w fizjologii i patologii człowieka. Now Lek. 2007, 76 (4), 349-356.

6. Chatterjee I.B., Majumder A.K., Nandi B.K., Subramanian N.: Synthesis and some major functions of vitamin $C$ in animals. Annals of the New York Academy of Sciences, Second Conference on Vitamin C, September 1975, 258, 24-47.

7. Żywienie człowieka. Podstawy nauki o żywieniu. Ed. J. Gawęcki. PWN, Warszawa 2010, 271-276.

8. Roth K., Streller S.: Vitamin C Deficiency - Part 4. Chemie in Unserer Zeit/ Wiley-VCH 2014, DOI: 10.1002/chemv.201400023.

9. Chemia żywności odżywcze i zdrowotne właściwości składników żywności. Ed. J. Gawęcki. Wyd. Nauk.-Tech., Warszawa 2007, 34-37.

10. Miktus M.: Witaminy część II: ogólna charakterystyka witaminy C. Żywienie i Zdrowie. 2000, 3, 1 (12), 1-4.

11. Farbstein D., Kozak-Blickstein A., Levy A. P.: Antioxidant vitamins and their use in preventing cardiovascular disease. Molecules. 2010, 15 (11), 8098-8110.

12. Grajek $W$ : Rola przeciwutleniaczy w zmniejszaniu ryzyka wystąpienia nowotworów i chorób układu krążenia. Żywn Nauka Technol Jakość. 2004, 1 (38), 3-11.

13. Zhang P. Y., Xu X., Li X. C.: Cardiovascular diseases: oxidative damage and antioxidant protection. Eur Rev Med Pharmacol Sci. 2014, 18 (20), 3091-3096.

14. Piasek A., Bartoszek A., Namieśnik J.: Substancje pochodzenia roślinnego przeciwdziałające kardiotoksyczności towarzyszącej chemioterapii nowotworów. Post Hig Med Dośw. 2009, 63, 142-158.

15. Szymańska-PasternakJ., Janicka A., Bober J.: Witamina C jako oręż w walce z rakiem. Onkol Prakt Klin. 2014, 7 (1), 9-23.

16. Sroka Z., Gamian A., Cisowski W.: Niskocząsteczkowe związki przeciwutleniające pochodzenia naturalnego. Post Hig Med Dośw. 2005, 59, 34-41.

17. Normy żywienia dla populacji polskiej - nowelizacja. Ed. M. Jarosz. Instytut Żywności i Żywienia, Warszawa 2012, 106-107.

18. Tabatabaei-Malazy O., Nikfar S., Laridżani B., Abdollahi M.: Influence of ascorbic acid supplementation on type 2 diabetes mellitus in observational and randomized controlled trials; a systematic review with meta-analysis. J Pharm Pharm Sci. 2014, 17 (4), 554-582

19. Dmowski P., Śmiechowska M., Prystupa A.: Aktywność antyoksydacyjna wybranych naparów Ilex paraguariensis dostępnych na rynku trójmiasta. Bromat Chem Toksykol. 2011, 3, 620-624.

20. Yuan M., Jia X., Ding C., Yuan S., Zhang Z., Chen Y.: Comparative studies on bioactive constituents in Hawk tea infusions with different maturity degree and their antioxidant activities. Sci World J. 2014, http://dx.doi. org/10.1155/2014/838165.

21. Skalozubova T., Reshetova V., Sorokina A., Markaryan A., Glazkova I.: Leaves of common nettle (Urtica dioica L.) as a source of ascorbic acid (Vitamin C). World Appl Sci J. 2013, 28 (2), 250-253.

22. Grimm H.U.: Chemia w pożywieniu. Jak działają dodatki do żywności i dlaczego nam szkodzą. Vital, Białystok 2014, 169-170.

23. Peckenpaugh N. J.: Podstawy żywienia i dietoterapia. Wyd. Urban \& Partner, Wrocław 2011, 107-109.

24. Buba F., Gidado A., Shugaba A.: Analysis of biochemical composition of honey samples from North-East Nigeria. Biochem Anal Biochem. 2013, 2 (3), 139 doi: 10.4172/2161-1009.1000139.

25. Burdurlu H.S., Koca N., Karadeniz F.: Degradation of vitamin C in citrus juice concentrates during storage. J Food Eng. 2006, 74 (2), 211-216.

26. Nemo O.: Witaminy - prawda i mity. http://www.biotechnologia.uni. opole.pl/biblioteka/docs/WITAMINY-PRAWDA-I-MITY.pdf (04.07.2015). 